\title{
TEMPAT TUMBUH DAN KANDUNGAN FLAVONOID TOTAL DAUN TABAT BARITO (Ficus deltoidea Jack.)
}

\author{
Siswoyo $^{1,2}$, Irmanida Batubara ${ }^{1,3, *}$, Devi Aristyanti ${ }^{2}$ \\ ${ }^{1}$ Pusat Studi Biofarmaka LPPM Institut Pertanian Bogor, Bogor, Jawa Barat \\ ${ }^{2}$ Departemen Konservasi Sumberdaya Hutan dan Ekowisata, Fakultas Kehutanan Institut \\ Pertanian Bogor, Bogor, Jawa Barat \\ ${ }^{3}$ Departemen Kimia, Fakultas MIPA, Institut Pertanian Bogor, Bogor, Jawa Barat \\ *Email: ime@apps.ipb.ac.id
}

\begin{abstract}
ABSTRAK
Tujuan penelitian ini ialah mengetahui perbedaan kadar bahan aktif yaitu flavonoid daun tabat barito (Ficus deltoidea Jack.) pada dua tempat tumbuh yang berbeda. Daun tabat barito dikoleksi dari Taman Nasional Gunung Gede Pangrango (TNGGP) dan Taman Nasional Gunung Halimun Salak (TNGHS). Tabat barito di TNGGP yang digunakan dalam penelitian tumbuh sebagai efifit, sedangkan di TNGHS tumbuh di atas tanah. Daun tanaman diekstraksi dengan etil asetat lalu ditentukan kadar total flavonoidnya menggunakan spektrometri. Hasil penelitian menunjukkan kadar flavonoid daun tabat barito TNGHS lebih rendah dibandingkan daun tabat barito TNGGP. Perbedaan kadar flavonoid diduga karena perbedaan kadar kimia tanah pada kedua lokasi.
\end{abstract}

Kata Kunci: epifit, flavonoid, kimia tanah, Ficus deltoidea Jack

\begin{abstract}
The aim of this research is to find the differences of active component/flavonoid content of tabat barito (Ficul deltoidea Jack) leaves on two different places. The tabat barito leaves were collected from Gede Pangrango National Park (TNGGP) and Halimun Salak National Park (TNGHS). Tabat barito in TNGGP which used in this research grew as epifit, while from TNGHS grew in the land. The tabat barito leaves was dried in the oven and grounded prior to extraction process by ethyl acetic. The flavonoid content was determined by spectrometric. The results showed that the flavonoid content of tabat barito leaves in TNGHS is lower than in TNGGP. The differences might be due to the differences of chemical content in the location.
\end{abstract}

Keywords: epifit, flavonoid, chemicals in soil, Ficus deltoidea Jack

\section{PENDAHULUAN}

Salah satu tumbuhan obat yang telah digunakan oleh leluhur Indonesia adalah Tabat barito (Ficus deltoidea Jack.). Tumbuhan ini biasa digunakan di Kalimantan sebagai aprodisiak wanita. Tabat barito tersebar di beberapa wilayah Indonesia seperti Sumatera, Jawa Barat, Kalimantan, dan Sulawesi dan tergolong tumbuhan ekoton (tumbuhan yang dapat hidup secara optimal di daerah peralihan dua ekosistem) dan tersebar di kisaran ketinggian tempat 450-2400 meter di permukaan laut [1]. Secara umum tumbuhan ini 
hidup sebagai tumbuhan epifit di dalam hutan dan mulai diteliti manfaatnya secara mendalam akhir-akhir ini.

Beberapa penelitian terkait efek dari tanaman ini telah dilaporkan seperti sebagai penurun kadar gula darah [2-7], antinociceptive [8], antioksidan [9-11], penyembuh luka [12], pemutih [13], antiinflamasi [14], dan lain-lain. Aktivitas yang ditunjukkan oleh tabat barito disebabkan ketersediaan bahan aktif di dalamnya.

Daun tabat barito mengandung zat ekstraktif utama berupa triterpenoid dan flavonoid [15]. Di samping itu, dari kedua kelompok zat ekstraktif tersebut, kelompok senyawa yang dilaporkan bertanggung jawab terhadap aktivitas daun tabat barito yang dilaporkan adalah flavonoid, seperti vitexin dan isovitexin yang memiliki aktivitas menghambat kerja enzim $\alpha$-glukosidase [6], serta flavonoid glikosida dan antosianin sebagai antioksidan [11]. Keberadaan kelompok senyawa ini dapat dijadikan parameter standardisasi daun tabat barito [16]. Standardisasi dilakukan tidak hanya pada produk yang akan dibuat melainkan mulai dari bibit, budidaya, pasca panen, hingga menjadi produk. Profil fitokimia daun yang segar dan tua akibat penyimpanan telah dilaporkan oleh Chua \& Hidayathulla [17]. Di sisi lain, efek tempat tumbuh terhadap kadar bahan aktif seperti flavonoid belum banyak dilaporkan. Oleh karena itu penelitian ini bertujuan mengetahui kadar flavonoid daun tabat barito dari dua tempat tumbuh yang berbeda yaitu pada Taman Nasional Gunung Gede Pangrango (TNGGP) dan Taman Nasional Gunung Halimun Salak (TNGHS).

\section{METODE PENELITIAN}

Penelitian dimulai dengan mengambil daun tabat barito dan juga sampel tanah pada dua tempat berbeda yaitu Taman Nasional Gunung Gede Pangrango (TNGGP) dan Taman Nasional Gunung Halimun Salak (TNGHS). Daun tabat barito dikeringkan menggunakan oven pada suhu $34^{\circ} \mathrm{C}$, setelah kering daun dibuat serbuk. Serbuk daun tabat barito kemudian dianalisis kandungan fitokimia dan diekstraksi menggunakan etil asetat sebelum ditentukan kandungan flavonoid totalnya.

\section{Bahan}

Bahan yang digunakan adalah daun tabat barito dan tanah pada dua tempat berbeda yaitu Taman Nasional Gunung Gede Pangrango (TNGGP) dan Taman Nasional Gunung Halimun Salak (TNGHS). Bahan kimia yang digunakan adalah etil asetat (pa, Sigma),

\section{Peralatan}

Alat yang digunakan adalah satu set alat Soxhlet, oven, neraca, spektrofotometer UV-Vis, AAS, dan peralatan gelas lainnya.

\section{Prosedur}

\section{Pengumpulan dan Pengeringan Sampel [18]}

Daun tabat barito yang didapat dipotong-potong dan dikeringkan pada suhu $40{ }^{\circ} \mathrm{C}$. Daun yang sudah kering diserbukkan dan disaring dengan ukuran 60 mesh di SEAFAST IPB.

\section{Penentuan Kadar Air dan Kadar Abu [19]}

Cawan porselin dikeringkan di dalam oven pada suhu $105-110{ }^{\circ} \mathrm{C}$ selama 15 menit, kemudian diletakkan di dalam desikator selama 30 menit dan ditimbang hingga diperoleh bobot konstan. Sebanyak $2 \mathrm{~g}$ sampel diletakkan dalam cawan yang telah dikeringkan tersebut, lalu dipanaskan di dalam oven pada suhu $105-110{ }^{\circ} \mathrm{C}$ hingga diperoleh bobot konstan. 
Untuk penentuan kadar abu, cawan porselin dikeringkan di dalam oven selama 30 menit pada suhu $100-105{ }^{\circ} \mathrm{C}$, lalu dimasukkan ke dalam tanur, setelah 30 menit cawan didinginkan di dalam desikator dan ditimbang. Sebanyak $2 \mathrm{~g}$ sampel diletakkan dalam cawan yang telah dikeringkan tersebut, lalu dibakar menggunakan pembakar bunsen hingga tidak berasap. Kemudian diabukan di dalam tanur pada suhu $600{ }^{\circ} \mathrm{C}$ hingga sempurna. Setelah itu, didinginkan di dalam desikator dan ditimbang.

\section{Ekstraksi}

Serbuk daun tabat barito ditimbang masing-masing sekitar 5 gram kemudian dimasukkan ke dalam timbel. Ekstraksi dilakukan menggunakan alat Soxhlet dengan pelarut etil asetat selama 5-6 jam. Ekstrak yang didapat dipekatkan hingga kering dan ditentukan rendemennya serta ditentukan kandungan flavonoidnya.

\section{Kadar Flavonoid [20]}

Total flavonoid diukur dengan uji kolorimetrik aluminium klorida. Sebanyak $125 \mu \mathrm{L}$ larutan ekstrak dicampurkan dengan $375 \mu \mathrm{L}$ etanol, $25 \mu \mathrm{L} \mathrm{AlCl}_{3} 10 \%, 25 \mu \mathrm{L} \mathrm{CH}_{3} \mathrm{COONa}$ $1 \mathrm{M}$, dan $700 \mu \mathrm{L}$ akuades. Kemudian campuran diaduk dan diinkubasi pada suhu ruang selama 30 menit. Sebanyak $250 \mu \mathrm{L}$ campuran dimasukkan ke dalam sumur (96-plate well) dan absorbans diukur pada panjang gelombang $415 \mathrm{~nm}$. Kuersetin digunakan sebagai standar. Kadar flavonoid dalam satuan (\%b/b (g/g)) ekstrak.

\section{Analisis Kandungan Kimia Tanah}

Penelitian ini menganalisis $\mathrm{pH}$ dan kandungan kimia tanah yaitu $\mathrm{N}, \mathrm{P}, \mathrm{K}, \mathrm{Ca}, \mathrm{Mg}$, dan $\mathrm{S}$. Sampel tanah diambil dengan cara membuat galian tanah di sekitar tajuk pohon sampel dengan kedalaman sekitar $30 \mathrm{~cm}$ atau hingga horizon B tanah tampak. Sampel tanah tabat barito yang berupa epifit merupakan sampel tanah yang berada di sekitar tajuk pohon induk yang ditumpangi.

\section{HASIL DAN PEMBAHASAN}

Tabat barito (F.deltoidea) adalah salah satu tumbuhan obat tradisional yang banyak ditemukan dikawasan belukar tepi laut atau rimba di pegunungan tetapi tidak tumbuh di kawasan hutan bakau [21]. Tumbuhan ini berupa perdu dan hidup epifit pada tumbuhan lain [21]. Secara alamiah, tabat barito ditemukan tumbuh di atas bebatuan dengan sedikit tanah dan humus hasil guguran daun, atau sebagai epifit pada tumbuhan lain untuk memperoleh intensitas cahaya yang cukup serta umum ditemukan pada kawasan hutan atau area yang terbuka [22].

Berdasarkan pengamatan visual yang dilakukan pada penelitian ini, tabat barito yang ditemui di Kawah Ratu (TNGHS) memiliki struktur tubuh berupa semak (Gambar 1), sedangkan tabat barito yang ditemui di sekitar pusat informasi (TNGGP) memiliki struktur tubuh berupa epifit (Gambar 2). Sifat morfologis dari tabat barito yang berupa semak, yaitu batangnya mampu tumbuh dengan baik, memanjang maupun bercabang. Selain itu, batang tabat barito sangat banyak mendukung daun dan berukuran kecil sehingga tumbuhnya rebah, begitu batang bertemu dengan media yang mengandung tanah atau humus segera berakar sehingga selalu merumpun. Tabat barito yang tumbuh sebagai epifit adalah tumbuhan yang menumpang pada tumbuhan lain. Namun, tabat barito yang berupa epifit tidak bergantung hidupnya pada bahan makanan yang berasal dari tumbuhan lainnya yang ditempeli, karena dia mendapat unsur hara dari mineral-mineral yang terbawa oleh udara, air hujan, atau aliran batang dan cabang tumbuhan lain[22]. 


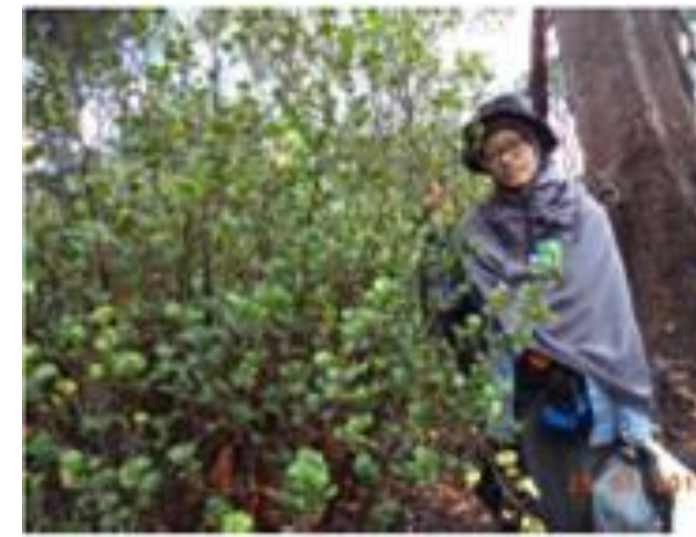

(a)

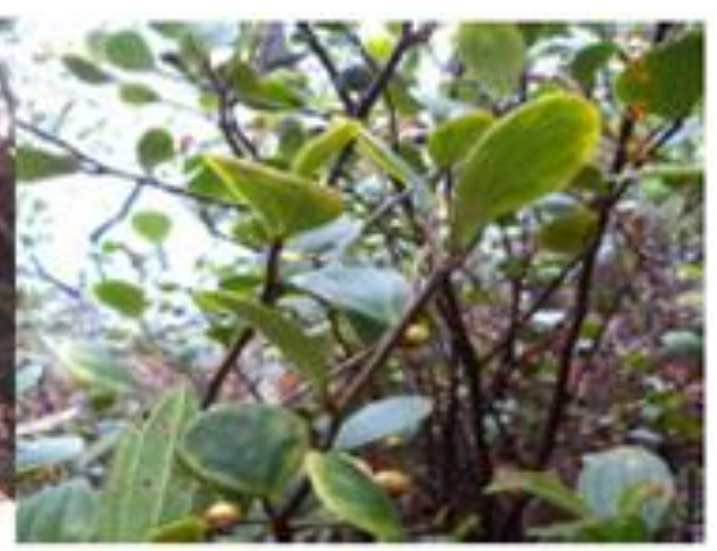

(b)

Gambar 1 Struktur tubuh tabat barito di seitar pusat informasi (TNGGP) (a) epifit (b) daun

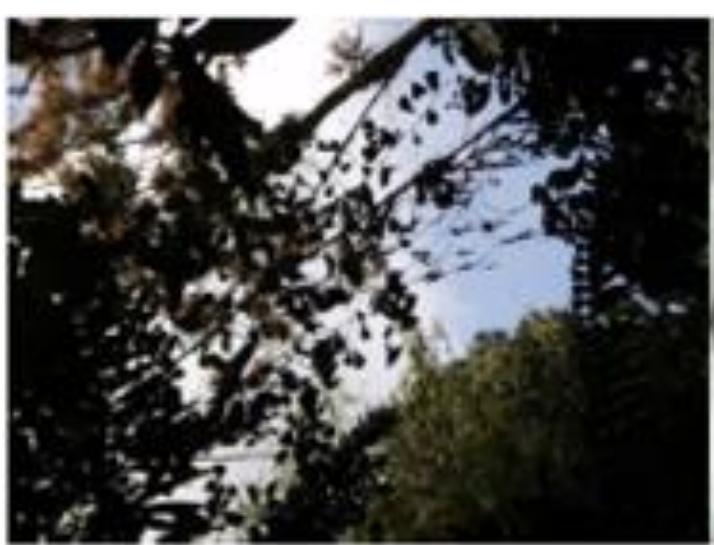

(a)

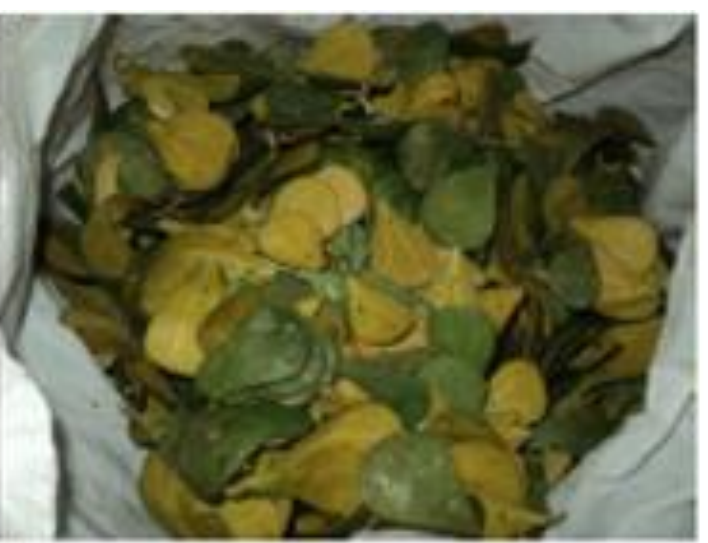

(b)

Gambar 2 Struktur tubuh tabat barito di Kawah Ratu (TNGHS) (a) semak (b) daun

Hasil analisis kimia tanah yang digunakan ini tumbuh menunjukkan bahwa kandungan kimia makro kedua tanah tersebut berbeda (Tabel 1). Kadar unsur makro tanah yang berada di sekitar pusat informasi (TNGGP) lebih tinggi jika dibandingkan dengan kandungan kimia tanah makro yang berada di Kawah Ratu (TNGHS), .

Tabel 1. Kandungan kimia makro tanah tempat tumbuh kedua daun tabat barito

\begin{tabular}{llcc}
\hline Kandungan yang & satuan & \multicolumn{2}{c}{ Lokasi } \\
\cline { 3 - 4 } ditentukan & & TNGHS & TNGGP \\
\hline $\mathrm{pH}\left(1: 1\right.$ dalam $\left.\mathrm{H}_{2} \mathrm{O}\right)$ & & 4.20 & 6.00 \\
$\mathrm{~N}$-total $($ Kjehdhal) & $\%$ & 0.08 & 0.60 \\
$\mathrm{P}($ Bray I) & $\mathrm{ppm}$ & 8.80 & 21.50 \\
$\mathrm{P}(\mathrm{HCl} \mathrm{25 \% )}$ & $\mathrm{ppm}$ & 81.10 & 197.10 \\
$\mathrm{~K}(\mathrm{HCl} \mathrm{25 \% )}$ & $\mathrm{ppm}$ & 61.43 & 240.35 \\
$\mathrm{Ca}(\mathrm{HCl} \mathrm{25 \% )}$ & $\mathrm{me} / 100 \mathrm{~g}$ & 0.79 & 16.99 \\
$\mathrm{Mg}(\mathrm{HCl} \mathrm{25 \% )}$ & $\mathrm{me} / 100 \mathrm{~g}$ & 1.18 & 6.45 \\
$\mathrm{Ca}\left(\mathrm{NH}_{4} \mathrm{OAc}, \mathrm{pH} 7\right)$ & $\mathrm{me} / 100 \mathrm{~g}$ & 0.26 & 25.23 \\
$\mathrm{Mg}\left(\mathrm{NH}_{4} \mathrm{OAc}, \mathrm{pH} 7\right)$ & $\mathrm{me} / 100 \mathrm{~g}$ & 0.23 & 0.31 \\
$\mathrm{~K}\left(\mathrm{NH}_{4} \mathrm{OAc}, \mathrm{pH} 7\right)$ & $\mathrm{me} / 100 \mathrm{~g}$ & 0.10 & 0.56 \\
$\mathrm{~S}$ tersedia & $\mathrm{me} / 100 \mathrm{~g}$ & 7.65 & 10.20 \\
$\mathrm{~S}$ total & $\mathrm{me} / 100 \mathrm{~g}$ & 78.54 & 94.25 \\
\hline
\end{tabular}


Tabat barito merupakan salah satu spesies dari famili Moraceae. Tumbuhan ini tergolong semak dan berakar tunggang. Batang tabat barito tegak, berkayu, bercabang banyak, bergetah, dan berwarna coklat. Daun tabat barito tunggal, tersusun zig zag, bertangkai panjang dengan ukuran $0,1-9 \mathrm{~cm}$, tebal $1-5 \mathrm{~mm}$, berbentuk bulat telur hingga lanset dengan permukaan daun licin mengkilap dan berwarna hijau kekuningan. Bunga tabat barito tunggal atau berpasangan dan berwarna kuning kejinggaan hingga coklat kemerahan. Buah tabat barito bulat hingga lonjong dengan biji berwarna coklat dan buahnya dapat dimakan setelah masak [1].

Hasil pengamatan menunjukkan bahwa tabat barito yang berada di Kawah Ratu (TNGHS) memiliki warna daun yang lebih kuning dibandingkan dengan tabat barito yang berada di TNGGP yang berwarna hijau lebih gelap. Selain itu, tabat barito yang berada di TNGHS memiliki ketebalan daun yang lebih kecil dibandingkan dengan tabat barito yang berada di TNGHS. Adapun salah satu penyebab yang memungkinkan terjadinya perbedaan ini adalah kadar kimia tanah yang terdapat pada kedua lokasi sampel diambil.

Unsur kimia tanah yang dibutuhkan dalam kadar banyak dikenal dengan nama unsur hara makro sedangkan unsur hara yang hanya dibutuhkan dalam jumlah sedikit jika dibandingkan dengan unsur hara makro dikenal dengan nama unsur hara mikro. Adapun unsur kimia tanah makro yang paling banyak menimbulkan gejala defisiensi adalah nitrogen, fosforus, dan kalium. Kandungan nitrogen yang berada di TNGHS lebih rendah jika dibandingkan dengan kandungan nitrogen yang berada di TNGGP. Nitrogen berfungsi membentuk zat hijau daun yang berguna dalam proses fotosintesis, pembentuk lemak dan senyawa organik lainnya [1]. Oleh karena itu, kekurangan nitrogen dapat mengganggu proses pertumbuhan tanaman dan menyebabkan tanaman menjadi kerdil, menguning dan menurun berat keringnya [1].

Kadar fosforus yang berada di TNGHS juga lebih rendah jika dibandingkan dengan kandungan fosforus yang berada di TNGGP. Kekurangan fosforus dapat menyebabkan penimbunan gula dalam bentuk pigmentasi antosianin pada bagian dasar batang dan daun [1]. Selain itu, kandungan kalium yang berada di TNGHS juga lebih rendah dibandingkan dengan kandungan kalium yang ada di TNGGP. Padahal, kalium merupakan unsur kimia yang berperan dalam proses metabolisme dan berpengaruh khusus dalam adsorbsi hara, pengaturan respirasi, transpirasi, kerja enzim dan dalam translokasi karbohidrat [1].

Dugaan kadar kimia tanah makro sebagai salah satu penyebab gejala defisensi yang berupa warna daun yang lebih kuning dan ketebalan daun yang lebih tipis pada tabat barito yang berada di Kawah Ratu (TNGHS) didukung oleh suatu penelitian sebelumnya mengenai teknik budidaya tabat barito secara in vitro di dalam rumah kaca yang menggunakan bibit tabat barito hasil cabutan dari alam (stump). Stump tersebut kemudian ditumbuhkan pada dua media utama yang berbeda, yaitu media topsoil dan media pasir. Hasil penelitian menunjukkan bahwa tabat barito yang tumbuh dengan menggunakan media topsoil memiliki pertambahan tinggi dan jumlah daun yang lebih besar dibandingkan dengan stump tabat barito yang ditumbuhkan pada media pasir [1].

Menurut hukum minimum Liebig, untuk dapat bertahan hidup di dalam keadaan tertentu, suatu organisme harus memiliki bahan-bahan yang penting yang diperlukan untuk pertumbuhan dan berkembangbiak. Keperluan-keperluan ini bervariasi antara jenis dan keadaan. Selain itu, menurut hukum toleransi Shelford, dikatakan bahwa kehadiran dan keberhasilan suatu organisme tergantung pada lengkapnya kompleks-kompleks keadaan. Ketiadaan atau kegagalan suatu organisme dapat dikendalikan oleh kekurangan atau kelebihan secara kualitatif atau kuantitatif dari salah satu dari beberapa faktor yang mungkin mendekati batas-batas toleransi organisme tersebut. Faktor-faktor yang mempengaruhi pertumbuhan tanaman tersebut kemudian dikenal dengan istilah faktor 
lingkungan. Adapun faktor lingkungan tersebut adalah cahaya, tunjangan mekanik, suhu, udara, air dan unsur hara. Beberapa faktor lingkungan di atas, menunjukkan bahwa unsur hara merupakan faktor yang berpengaruh terhadap pertumbuhan normal suatu tanaman [23]. Berikut ini merupakan gambar tanah sampel yang berasal dari TNGHS dan TNGGP (Gambar 3a dan b).

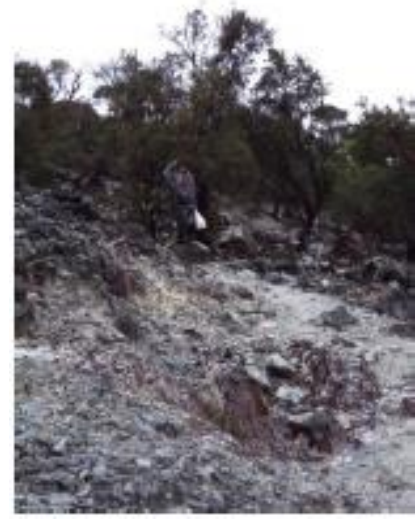

(a)

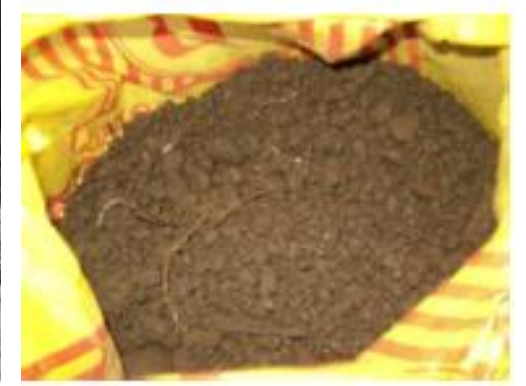

(b)

Gambar 3. Tanah di TNGHS (a) dan TNGGP (b)

Hasil uji kimia tanah berikutnya menunjukkan jika $\mathrm{pH}$ tanah di habitat lokasi tumbuh tabat barito sampel memiliki perbedaan, yaitu 4.20 untuk di TNGHS dan 6.00 untuk di TNGGP. Secara umum, pH berperan penting dalam mengatur respirasi dan sistem-sistem enzim di dalam tubuh dan perbedaan kadar yang sangat sedikit atas kebutuhan suatu komponen terhadap enzim dapat membuat situasi yang cukup buruk. Perubahan $\mathrm{pH}$ berbanding dengan perubahan $\mathrm{CO} 2$ dan hal inilah yang membuat $\mathrm{pH}$ menjadi indikator yang berguna bagi laju metabolisme komunitas total (fotosintesis dan respirasi) [24]. Perbedaan $\mathrm{pH}$ tanah dari kedua lokasi penelitian juga turut mempengaruhi perbedaan kadar flavonoid yang terjadi pada ekstrak daun tabat barito. Hal ini dikarenakan tanah dan perairan yang memiliki $\mathrm{pH}$ berkadar rendah pada umumnya sering ditemui dalam kondisi kekurangan hara yang diikuti dengan tingkat produktivitas yang rendah pula.

Secara tradisional, tabat barito digunakan antara lain untuk pencegahan dan penyembuhan penyakit paru-paru basah, diabetes, darah tinggi, diare, melancarkan peredaran darah, mencegah infeksi kulit, memperlancar haid, pengobat keputihan, serta merapatkan Rahim setelah bersalin [21]. Ekstrak daun tabat barito dilaporkan mampu menghambat pertymbuhan sel tumor dan juga menghambat kerja enzim tirosin kinase [15]. Hal ini disebabkan karena keberadaan senyawa terutama golongan triterpenoid dan flavonoid.

Flavonoid berperan sebagai antioksidan dengan cara mendonasikan atom hidrogennya atau melalui kemampuannya mengkelat logam, berada dalam bentuk glukosida (mengandung rantai samping glukosa) atau dalam bentuk bebas yang disebut aglikon. Kandungan zat ekstraktif flavonoid daun tabat barito yang berasal dari Kawah Ratu (TNGHS) dan sekitar pusat informasi (TNGGP) menunjukkan hasil yang berbeda. Daun tabat barito yang berasal dari Kawah ratu yang merupakan daerah berkawah memiliki kadar flavonoid yang lebih rendah, yaitu $2.41 \%$ dibandingkan dengan kadar flavonoid yang berada di TNGGP, yaitu 3.54\% (Tabel 2). Meskipun tabat barito yang berada di TNGGP berupa epifit, namun epifit tidak bergantung hidup pada makanan yang berasal dari tanaman induknya. Sehingga perbedaan kadar flavonoid berhubunga dengan kondisi tanah tempat tumbuhnya. 
Tabel 2. Kadar flavonoid daun tabat barito dari TNGHS dan TNGGP

\begin{tabular}{lccc}
\hline & Ulangan & \multicolumn{2}{c}{ Lokasi habitat tumbuh } \\
\cline { 3 - 4 } & & TNGHS & TNGGP \\
\hline Kadar flavonoid (\%) & 1 & 2.37 & 3.43 \\
& 2 & 2.61 & 3.84 \\
& 3 & 2.25 & 3.34 \\
& rerata & 2.41 & 3.54 \\
\hline
\end{tabular}

Flavonoid merupakan salah satu dari banyak jenis metabolit sekunder. Metabolit sekunder merupakan senyawa yang dihasilkan atau disintesis pada sel dan grup taksonomi tertentu pada tingkat pertumbuhan atau stress tertentu. Senyawa ini diproduksi hanya dalam jumlah sedikit tidak terus menerus untuk mempertahankan diri dari habitatnya dan tidak berperan penting dalam proses metabolism utama (primer). Pada tanaman, senyawa metabolit sekunder memiliki beberapa fungsi, diantaranya sebagai atraktan (menarik serangga penyerbuk), melindungi dari stress lingkungan, pelindung dari serangan hama/penyakit (phytoaleksin), pelindung terhadap sinar UV, sebagai zat pengatur tumbuh dan untuk bersaing dengan tanaman lain (alelopati) [25]. Adapun faktor yang memengaruhi produksi metabolit sekunder, antara lain, kondisi tempat tumbuh, faktor fisik (suhu, cahaya, kelembaban dll), faktor genetik (genotipa sel), dan faktor stress lingkungan (logam berat, elicitor, sinar UV) [26].

Berdasarkan penelitian terdahulu yang dilakukan oleh Siswoyo (1999), diketahui bahwa tabat barito dengan pemberian kalsium yang tinggi memiliki kandungan flavonoid yang juga lebih tinggi [1]. Hal ini sesuai dengan hasil penelitian ini yaitu daun yang tumbuh pada daerah TNGGP yang memiliki kadar kalsium lebih tinggi, daunnya memiliki kadar flavonoid lebih tinggi. Kalsium berfungsi sebagai pengaktif enzim, terutama yang berhubungan dengan protein sehingga akan lebih mendukung proses terbentuknya metabolit sekunder yang merupakan reaksi spesifik, menggunakan katalisator enzimatik dengan bahan dasar yang berasal dari metabolisme primer untuk menghasilkan senyawasenyawa kompleks, salah satunya flavonoid. Dengan kata lain, kalsium merupakan salah satu faktor kunci selain N, P dan K yang menyebabkan kandungan flavonoid tinggi pada daun tabat barito.

\section{KESIMPULAN}

Kadar flavonoid daun tabat barito di sekitar pusat informasi (TNGGP) lebih tinggi, yaitu sebesar 3.54\% dibandingkan dengan yang tumbuh di Kawah Ratu(TNGHS) yang hanya sebesar $2.41 \%$. Hal ini diduga karena adanya perbedaan kadar kimia tanah dari kedua lokasi tersebut, terutama kadar N, P, K, dan Ca. Masih diperlukan penelitian terkait factor suhu dan struktur tubuh lainnya dari tabat barito terhadap kadar flavonoid.

\section{DAFTAR PUSTAKA}

1. Siswoyo. 1999. Pengaruh Pemberian Ekstrak Daun Tempuyung (Sonchus arvensisL.) ke dalam Beberapa Media Tumbuh terhadap Pertumbuhan dan Kandungan Bahan Bioaktif Daun Tabat Barito (Ficus deltoidea Jack.) [Thesis]. Bogor (ID) : Institut Pertanian Bogor.

2. Adam, Z., Hamid, M., Ismail, A., Khamis, S., 2007. Effect of Ficus deltoidea aqueous extract on blookd glucose level in normal and mild diabeteic rats. Malaysian J Health Sci 5(2):9-16.

3. Adam, Z., Hamid, M., Ismail, A., Khamis, S., 2009. Effect of Ficus deltoidea extract 
on hepatic basal and insulin stimulated glucose uptake. J Biol Sci 9:796-803

4. Adam, Z., Khamis, S., Ismail, A, Hamid, M., 2010. Inhibitory properties of Ficus deltoidea on a-glucosidase activity. Research Journal of Medicinal Plants 4(2):61-75

5. Adam, Z., Khamis, S., Ismail, A., Hamid, M., 2012. Ficus deltoidea: A potential alternative medicine for diabetes mellitus. Evid Based Complement Alternat Med 2012:632763

6. Choo, C.Y., Sulong, N.Y., Man, F., Wong, T.W., 2012. Vitexin and isovitexin from the leaves of Ficus deltoidea with in-vivo a-glucosidase inhibition. Journal of Ethnopharmacology 142(3):776-781

7. Misbah, H., Aziz, A.A., Aminudin, N., 2013. Antidiabetic and antioxidant properties of Ficus deltoidea fruit extracts and fraction. BMC Complementary and Alternative Medicine. 13:118

8. Sulaiman, M.R., Hussain, M. K., Zakaria Z.A., Somchit, M.N. 2008. Evaluation of the antinonciceptive activity of Ficus deltoidea aqueous extract. Fitoterapia 79(7-8):557561

9. Abdullah, Z., Hussain, K., Zhari, I., Rasadah, M.A., Mazura, P., Jamaludin, F., Sahdan, R., 2009. Evaluation of extracts of leaf of three Ficus deltoidea varieties for antioxidant activities and secondary metabolites. Pharmacognosy Research 1(4):216223

10. Hakiman, M, Maziah, M., 2009. Non enzymatic and enzymatic antioxidant activities in aqueous extract of different Ficus deltoidea accessions. Journal of Medicinal Plants Research 3(3):120-131

11. Omar, M.H., Mullen W., Crozier A., 2011. Identification of proanthocyanidin dimers and trimers, flavone C-glycosides, and antioxidants in Ficus deltoidea, a Malaysian herbal tea. J Agric. Food Chem. 59(4): 1363-1369

12. Abdulla, M. A., Ahmed, K.A., Abu-Luhoom, F.M., Muhanid, M., 2010. Role of Ficus deltoidea extract in the enhancement of wound healing in experimental rats. Biomedical Research 21(3):241-245.

13. Oh, M., Hamid M. A., Ngadiran, S., Seo, Y., Sarmidi, M.R., Park, C.S. 2011. Ficus deltoidea (Mas cotek) extract exerted anti-melanogenic activity by preventing tyrosinase activity in vitro and by suppressing tyrosinase gene expression in B16F1 melanoma cells. 303:161-170

14. Abdullah, Z., Hussain K, Ismail, Z., Ali, R.M. 2009. Anti-inflammatory activity of standardised extracts of leaves of three varieties of Ficus deltoidea. International Journal of Pharmaceutical and Clinical Research 1(3):100-105.

15. Darusman LK, Iswantini D, Djauhari E, Heryanto R. 2003. Ekstrak Tabat Barito Berkhasiat Anti Tumor : Kegunaan sebagai Jamu, Ekstrak Terstandar dan Bahan Fitofarmaka. [internet]. [diunduh 2012 November 10]. Tersedia dari : http://www.repository.ipb.ac.id/handle/123456789/4004

16. Shafaei, A., Farsi, E., Ahamed B.M.K., Siddiqui, M.J.A., Attitalla, I.H., Zhari, I., Asmawi, M.Z., 2011. Evaluation of toxicological and standardization parameters and phytochemical investigation of Ficus deltoidea leaves. Am J Biochem Mol Biol 1(3):237-243

17. Chua, L.S., Hidayathulla, S., 2015. Phytochemical profile of fresh and senescent leaves due to storage for Ficus deltoidea. Plant Biosystem doi:10.1080/11263504.2015.1076085

18. [BPOM] Badan Pengawas Obat dan makanan. 2004. Monografi Ekstrak Tumbuhan Obat Indonesia. Jakarta (ID): BPOM RI

19. [AOAC] Association of Official Analytical Chemist. 2006. Official Methods of AOAC International. Revisi ke-2. Vol ke-1. Maryland (US): Association of Official 
Analytical Chemist.

20. Chang C, Yang M, Wen H, Chern J. 2002. Estimation of total flavonoid content in propolis by two complementary colorimetric methods. J of Food and Drug Analysis. 10(3):178-182.

21. Suryati. 2011. Eludasi Struktur Steroid dari Daun Tabat Barito (Ficus deltoideus Jack.). Jurnal Poli Rekayasa. 6. [internet]. [diunduh 2014 Mei 14]. Tersedia dari : http ://www.ojs.polinpdg.ac.id/index.php/JPR/.../297

22. Arifin YF, Pujawati ED, Aqla M. 2011. Budidaya Tabat Barito (Ficus deltoidea Jack.) secara Stump dengan Variasi Perlakuan Media Tanam dan Pupuk Organik NASA. Jurnal Hutan Tropis. 12 : 125-131. [internet]. [diunduh 2014 Mei 14]. Tersedia dari : http ://www.ejournal.unlam.ac.id/index.php/jht/.../346

23. Nascimento LBdS, Leal-Costa MV, Menezes EA, Lopes VR, Muzitano MF, Costa SS, Tavares ES. 2015. Ultraviolet B-radiation effects on phenolic profile and flavonoid content Kalanchoe pinnata. Journal of Photochemistry and Photobiology B: Biology148:73-81

24. Atkin, O. K., Bloomfield, K. J., Reich, P. B., Tjoelker, M. G., Asner, G. P., Bonal, D., Bönisch, G., Bradford, M. G., Cernusak, L. A., Cosio, E. G., Creek, D., Crous, K. Y., Domingues, T. F., Dukes, J. S., Egerton, J. J. G., Evans, J. R., Farquhar, G. D., Fyllas, N. M., Gauthier, P. P. G., Gloor, E., Gimeno, T. E., Griffin, K. L., Guerrieri, R., Heskel, M. A., Huntingford, C., Ishida, F. Y., Kattge, J., Lambers, H., Liddell, M. J., Lloyd, J., Lusk, C. H., Martin, R. E., Maksimov, A. P., Maximov, T. C., Malhi, Y., Medlyn, B. E., Meir, P., Mercado, L. M., Mirotchnick, N., Ng, D., Niinemets, Ü., O'Sullivan, O. S., Phillips, O. L., Poorter, L., Poot, P., Prentice, I. C., Salinas, N., Rowland, L. M., Ryan, M. G., Sitch, S., Slot, M., Smith, N. G., Turnbull, M. H., VanderWel, M. C., Valladares, F., Veneklaas, E. J., Weerasinghe, L. K., Wirth, C., Wright, I. J., Wythers, K. R., Xiang, J., Xiang, S. and Zaragoza-Castells, J. 2015, Global variability in leaf respiration in relation to climate, plant functional types and leaf traits. New Phytol, 206: 614-636. doi:10.1111/nph.13253

25. Panhar A, Grotewold E, Doseff A, 2015. Flavonoid dietetics: mechanosms and emerging roles of plant nutraceuticals. Pigments in Fruits and Vegetables. Chapter 5. Pp 93-126

26. Pandey A, Misra P. Trivedi PK, 2015. Constitutive espression of Arabidopsis MYB transcription factor, AtMYB11, in tobacco modulates flavonoid biosynthesis in favor o flavonol accumulation. Plant cell reports. 34:1515-1528. Doi: 10.1007/s00299-0151803 